\title{
DEVELOPMENT OF COMPUTER PROGRAM FOR DETERMINATION BROODING ENERGY IN BROILER HOUSES
}

\author{
OBAIA, A. R.* and M.I. Ghazy **
}

\begin{abstract}
The present work was carried out at EL-Gabal EL-Akhdar region Bayda city, Libya. The objective of this work is to develop a simple computer program for defining the brooding energy of broiler houses under region conditions. The simple program written using MATLAB Version 12.0. Heat bird and heat losses for each of ventilation and a sensible heat for building were identified as the main parameters in investigated program. The program can predict the maximum brooding energy for broiler house under different weather conditions and expect number of brooding heaters. The results showed that the brooding energy per one day for old chickens were found to be 4.84, 4.03, 3.22, 2.42 and 1.61 W/bird at external house temperature $10,15,20,25$ and $30^{\circ} \mathrm{C}$ respectively. Whereas, the total brooding energy were recorded 10.56, 8.30, 6.04, 3.79 and 1.53 W/bird for birds at external house temperature 10, 15, 20, 25 and $30^{\circ} \mathrm{C}$ respectively. The top score of ventilation rate for broiler house was $40690 \mathrm{~m}^{3} / \mathrm{s}$.
\end{abstract}

\section{INTRODUCTION}

T $\mathrm{n}$ the past, broiler production was not recognized as an important occupation. But, it has developed and occupied a place of pride among the livestock enterprises due to its rapid monetary turnover (Amos, 2006). In poultry brooding, heating is vital in the first week for the development of the chicken before they become able to regulate their own body temperature. In their six-weeks brooding period, chicken are highly sensitive to the surrounding temperature that may harm their performance if low (Vigoderis et al., 2008). Moreover, as the chicken grows sufficient size and hair coverage, heating requirements decrease gradually with advanced stages in brooding according to ASHRAE recommendations (ASHRAE, 2011).

\footnotetext{
* Agric. Eng. Res. Institute, ARC, Dokki, Giza, Egypt.

**Agric. Eng. Dept., Fac. of Agric., Mansoura Univ.
} 
High environmental temperature is one of the most important stressors associated with economic losses to the poultry industry (Lin et al., 2006; Lu et al., 2007). It causes poor growth performance (Bottje and Harrison, 1985), immunosuppression (Young, 1990), and high mortality (Yahav et al., 1995), contributing thus to a decrease in productivity (Sandercock et al., 2001and Hashizawa et al., 2013). Although the responses to heat differ between chickens of different genetic backgrounds (Altan et al., 2003; Franco-Jimenez et al., 2007; Star et al., 2008 and Felver-Gant et al., 2012), broilers are in general more sensitive to high environmental temperatures than other domestic animals (Geraert et al., 1993). Indeed, domestication and selective breeding are producing individuals that are more susceptible to stress rather than more resistant (Washburn et al., 1980; Cahaner et al., 1995). In particular, the resistance to heat stress of strains selected for rapid growth is significantly lower than that of slow-growing strains and the continuous selection for fast growth seems to be associated with increased susceptibility of broiler chicken to heat stress (Berrong and Washburn, 1998; Tan et al., 2010; Soleimani et al., 2011). Cardeau and Barrington (2010) used the heat balance to valuate heat bird production under indoor conditions on two commercial broiler houses. The impact of solar heated ventilation air on bird performance and identify strategies to reduce winter heating load. The measured sensible and total heat productions of 4.5 and $8.4 \mathrm{~W}$ per one $\mathrm{kg}$ birds for corresponded to laboratory measured values. Room air temperature stratification resulted in $20-40 \mathrm{~kW}$ of heat losses during the winter, it representing $25 \%$ of the total natural gas heat load. Sustainable energy management in livestock houses requiring heating should incorporate an air mixing system to eliminate air temperature stratification and improve fan flows.

Energy analysis is the operation to be evaluate a new or modified production lines. Jekayinfa et al. (2007) specified that the energy intensity use on broiler farms as input or output energy pattern are very important. Therefore, the objective of this work was to develop a Computer Program for determination brooding energy of broiler house. 


\section{MATERIALS AND METHODS}

This work was conducted in a broiler house at EL-Gabal EL-Akhdar region Bayda city, Libya to develop a Computer Program for determination the balancing energy in broiler house. The computer program written using MATLAB Version 12.0.

\section{The specification of the broiler house}

An open broiler house with dimensions about $60 \mathrm{~m}$ length, $12 \mathrm{~m}$ width and $3.4 \mathrm{~m}$ height. It's constructed from brick with dimensions of $40 \times 25$ $\mathrm{cm}$ and shaded with sheets of Zink metal ( $2 \mathrm{~mm}$ thickness). The house direction was East-West and divided into 15 partitions. The common gas heating system was used during the brooding period. The third of the house is used during the first week for brooding heat, then the whole house area was used.

\section{The specification of climate condition}

Table (1) illustrated the mean temperature and relative humidity from October to September 2014/2015 at EL-Gabal EL-Akhdar region, Libya. The temperature varied from 9.1 to $30.3{ }^{\circ} \mathrm{C}$ and the relative humidity varied from 52.9 to $80.2 \%$ during the studied period.

\section{Temperature and relative humidity}

The daily dry and wet temperature was measured using thermometer with dry and wet bulb, respectively. The Psychometric chart used for determining the specification of the internal house air by knowing dry and wet temperature.

\section{The experimental procedure}

All data was used as inputs in the developed program [house specifications (length, widths and heights); internal house temperature $\left(35,30,27,24,21\right.$ and $\left.21^{\circ} \mathrm{C}\right)$ for first, second, three, four, five, and six weeks, respectively, and it were controlled by a thermostat, internal house relative to humidity was arranged from $60-80 \%$.

\section{The internal heat balance}

The concept of energy conservation is applied to sensible heat. Hence, the heat balance considered in this study addresses the sensible heat transfers. 
Table (1): The specification of climatic condition at EL-Gabal EL Akhdar region, Libya.

\begin{tabular}{|l|l|l|l|l|l|l|l|l|l|l|l|l|}
\hline \multirow{2}{*}{ Parameter } & \multicolumn{9}{|c|}{ Months } \\
\cline { 2 - 12 } & 10 & 11 & 12 & 1 & 2 & 3 & 4 & 5 & 6 & 7 & 8 & 9 \\
\hline $\begin{array}{l}\text { Mean } \\
\text { temperature } \\
\left({ }^{\circ} \text { C) }\right.\end{array}$ & 18.2 & 14.4 & 10.8 & 9.1 & 9.3 & 13.4 & 16.4 & 19.8 & 22.2 & 23.8 & 30.3 & 21.7 \\
\hline $\begin{array}{l}\text { Mean } \\
\text { relative } \\
\text { humidity (\%) }\end{array}$ & 72.3 & 72.0 & 64.6 & 80.2 & 78.2 & 65.2 & 57.8 & 52.9 & 54.0 & 63.8 & 53.2 & 62.7 \\
\hline
\end{tabular}

Therefore, the heat balance can be expressed from principle equation as follows:

$$
q_{s}+q_{m}+q_{s o}+q_{h}+q_{v i}=q_{w}+q_{f}+q_{e}+q_{v o}
$$

Where:

$q_{s}=$ sensible heat gain from birds within the air space (W).

$q_{m}=$ sensible heat gain from mechanical sources and electrical devices as the heat gain from conversion of mechanical and electrical energy to sensible heat which is small and can be neglected (W).

$q_{s o}=$ sensible heat gain from the sun (direct radiation, e.g. through windows) which is relatively small and can be neglected (W).

$q_{h}=$ sensible heat gain from the heating system which is not applicable for the house under consideration and then considered zero (W).

$q_{v i}=$ sensible heat contained in the ventilation air entering the space referenced to a temperature datum (W).

$q_{w}=$ transfer of sensible heat through the structural cover of the building (i.e. walls, ceiling, windows, doors, etc.) (W).

$q_{f}=$ sensible heat transfer to the floor of the building primarily at the perimeter (W).

$q_{e}=$ rate of conversion of sensible heat to latent heat within the airspace (e.g. evaporation of water from the floor of the house) 
$q_{v o}=$ sensible heat contained in the ventilation air leaving the space referenced to a temperature datum $(\mathrm{W})$.

If animal heat data are presented as net sensible heat production, the terms $\mathrm{q}_{\mathrm{s}}$ and $\mathrm{q}_{\mathrm{e}}$ are combined into one (Albright (1990). So, the change of sensible heat content of ventilation air is measured by its change of temperature, therefore:

$$
q_{v o}-q_{v i}=c_{p} \cdot \rho \cdot v_{H B}\left(t_{i}-t_{o}\right)
$$

Where:

$c_{p}=$ specific heat of the air which was considered as $1006 \mathrm{~J} / \mathrm{kg} .{ }^{\circ} \mathrm{C}$

$\rho=$ air density and is the inverse of the specific volume which was derived from the Psychometric charts using the dry-bulb temperature and the relative humidity $\left(\mathrm{kg} / \mathrm{m}^{3}\right)$

$v_{H B}=$ ventilation rate $\left(\mathrm{m}^{3} / \mathrm{s}\right)$

$t_{i}=$ air temperature inside the house,

$t_{o}=$ air temperature outside the house.

The structural heat loss was calculated as follows:

$$
\mathrm{q}_{w}=\sum U A \cdot\left(t_{i}-t_{o}\right)
$$

Where:

$U=$ the overall heat transfer coefficient of the building component under consideration $\left(\mathrm{W} / \mathrm{m}^{2}{ }^{\circ} \mathrm{C}\right)$

$$
A=\text { house area }\left(\mathrm{m}^{2}\right)
$$

The factor " $U$ " and "A" characterizes the overall conductance of the building shell and includes the effects of ceiling, walls, windows, and doors.

The heat exchange with the floor was calculated as follows:

$$
q_{f}=F \cdot P \cdot\left(t_{i}-t_{o}\right)
$$

Where:

$F=$ the perimeter heat loss factor and was considered as 1.5 $\mathrm{W} / \mathrm{m} .{ }^{\circ} \mathrm{C}$, according to Albright (1990) and Samer et al. (2011). 
$P=$ the perimeter length of the building under consideration (m).

The heat balance had been rearranged to calculate the ventilation rate, subject to the given conditions, as follows:

$$
v_{H B}=\frac{\left.q_{s}-\sum U A+F P\right) \cdot\left(t_{i}-t_{o}\right)}{c_{p} \cdot \rho \cdot\left(t_{i}-t_{o}\right)}
$$

\section{RESULTS AND DISCUSSION}

The input variables of investigated program were boiler house specification (length, width and heights), ' $\mathrm{K}$ " and " $\mathrm{H}$ " values, number of birds, internal temperature and relative humidity, external temperature and relative humidity, internal and external moisture content of air at saturation, sensible heat from birds, water vapor from birds and " $\mathrm{Co}_{2}$ " out.

Figure (1) illustrates the flowchart of the program that used for calculating the brooding energy per one day for old chickens and total energy for broiler house. The program was divided to two parts, the first part for input data and the second part for output data. The input data includes house length of $60 \mathrm{~m}$, width of $12 \mathrm{~m}$, heights of $3.4 \mathrm{~m}$, number of birds 7000 bird, mean bird mass at age of one day (50 gram); internal house temperature $\left(35,30,27,24,21\right.$ and $\left.21^{\circ} \mathrm{C}\right)$ for first, second, three, four, five, and six weeks, respectively. Internal house relative humidity was arranged from 60-80\%. Maximum external temperature was $30.3{ }^{\circ} \mathrm{C}$, minimum external temperature was $9.1^{\circ} \mathrm{C}$ and average external temperature was $17.4{ }^{\circ} \mathrm{C}$. Maximum external house relative humidity was $80.2 \%$, minimum external house relative humidity was $52.9 \%$ and average external house relative humidity was $64.7 \%$. Equations from 1 to 5 using for calculating ventilation heat losses by infiltration, heat losses from building, minimum ventilation according to moisture balance, minimum ventilation according to $\mathrm{Co}_{2}$ balance, maximum ventilation requirement. All of this outputs were used for determining the brooding energy of broiler house.

The effect of external house temperature of $10,15,20,25$ and $30^{\circ} \mathrm{C}$ on brooding energy for one day old chickens were investigated and illustrated in Figures (2). 
4

Read house specifications, number of birds, temerature and relative humidity internal and external $\uparrow$

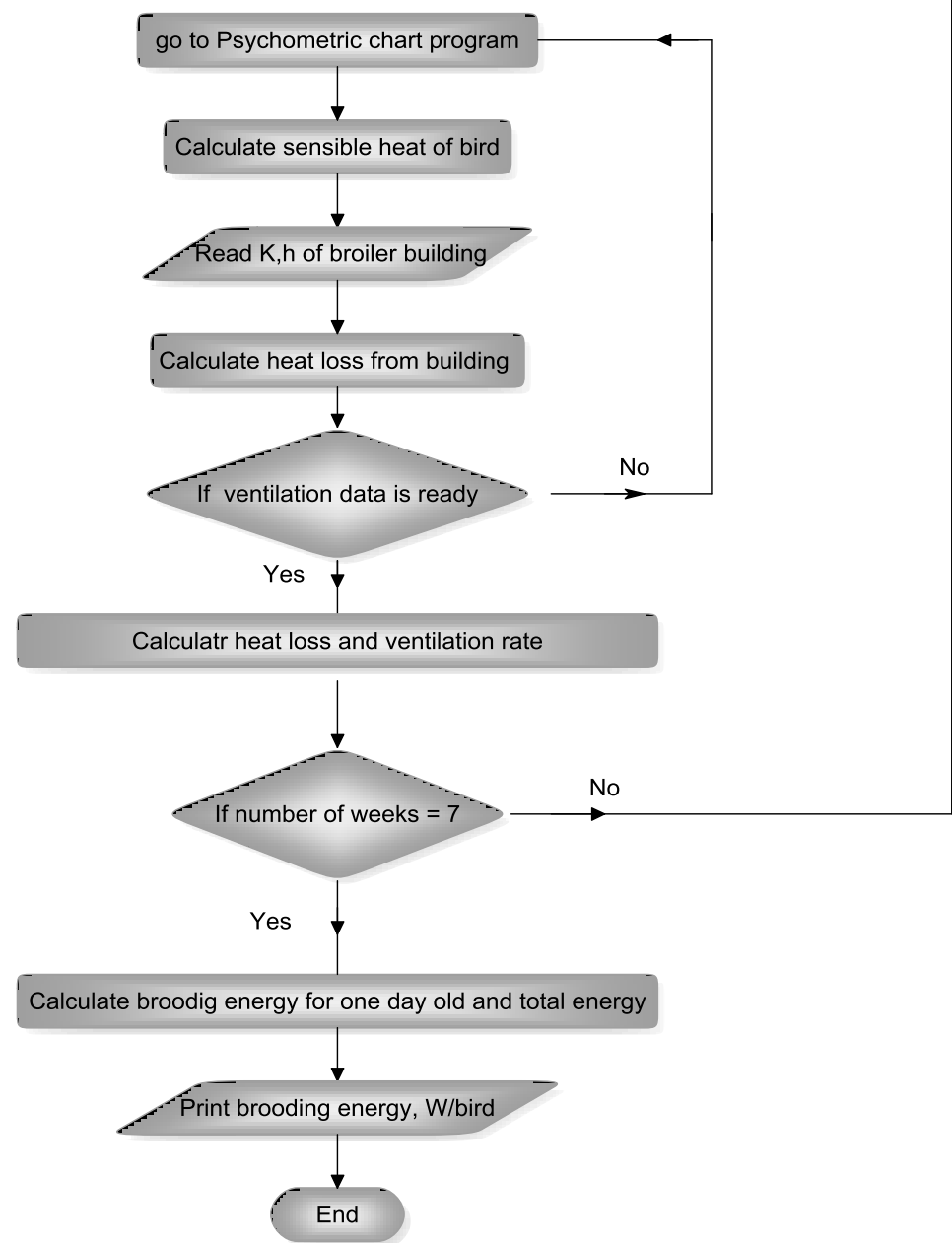

Fig. (1): A Flow chart for brooding energy program.

As shown in Figure (2) brooding energy per one day for old chickens were decreased from a level of $4.84 \mathrm{~W} / \mathrm{bird}$ to $1.61 \mathrm{~W} / \mathrm{bird}$ for external house temperature of $10^{\circ} \mathrm{C}$ to $30^{\circ} \mathrm{C}$, respectively.

The effect of external house temperature of $10,15,20,25$ and $30^{\circ} \mathrm{C}$ on total brooding energy for birds were investigated and illustrated in Figures (3). As shown in Figure (3) the brooding energy for total 
brooding energy for birds were decreased from a level of $10.56 \mathrm{~W} / \mathrm{bird}$ to a level of $1.53 \mathrm{~W} / \mathrm{bird}$ for external house temperature of $10{ }^{\circ} \mathrm{C}$ to $30{ }^{\circ} \mathrm{C}$, respectively. It can be said that, the external house temperature plays an important role in brooding energy consumption of broiler house. The maximum ventilation rate requirement will occur with the largest birds. The house is assumed to be located where $30{ }^{\circ} \mathrm{C}$. The maximum ventilation rate for broiler house was $40690 \mathrm{~m}^{3} / \mathrm{s}$. The program can be predict the amount of brooding energy under the condition of different climatic regions by input the pervious data.
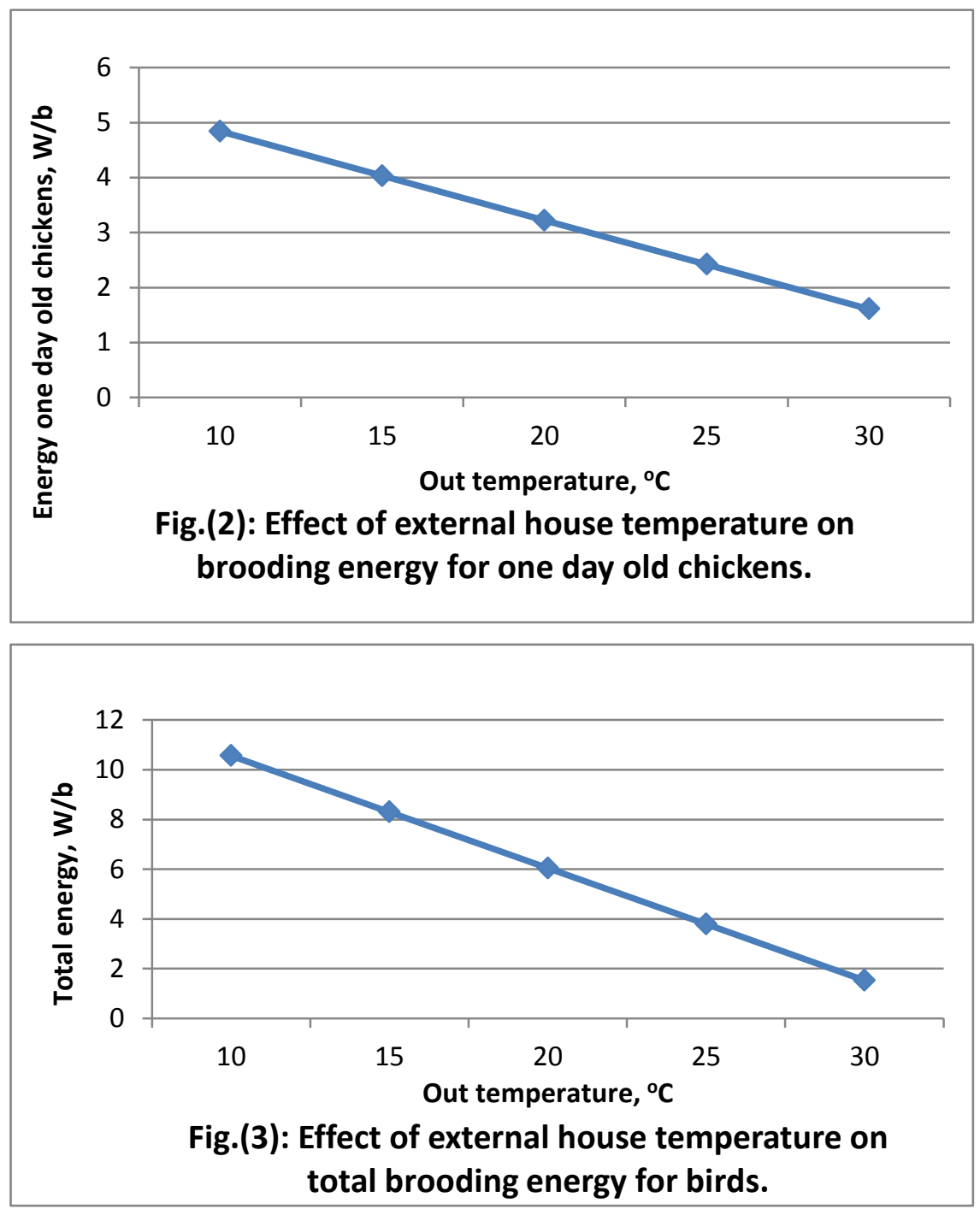


\section{CONCLOSION}

From this investigation the following conclusions can be made:

1. The brooding energy per one day for old chickens were found to be $4.84,4.03,3.22,2.42$ and $1.61 \mathrm{~W} / \mathrm{bird}$ at external house temperature $10,15,20,25$ and $30^{\circ} \mathrm{C}$ respectively.

2. The total brooding energy were recorded 10.56, 8.30, 6.04, 3.79 and $1.53 \mathrm{~W} / \mathrm{bird}$ for birds at external house temperature 10, 15, 20,25 and $30^{\circ} \mathrm{C}$ respectively.

3. The top score of ventilation rate for broiler house was $40690 \mathrm{~m}^{3} / \mathrm{s}$.

\section{REFERENCES}

Altan, O., Pabuccuoğlu, A., Altan, A., Konyalioğlu, S., Bayraktar, H., 2003. Effect of heat stress on oxidative stress, lipid peroxidation and some stress parameters in broilers. Br. Poult. Sci. 44, 545-550.

Albright L.D. (1990) .Environment Control for Animals and Plants, ASAE, St. Joseph, Michigan, USA.

Amos T.T. (2006). Analysis of backyard poultry production in Ondo state, Nigeria. Int. J. Poult. Sci.; 5(3): 247-250.

ASHRAE (2011). Environmental Control for Animals and Plants. HVAC Applications, ASHRAE Inc., Atlanta, GA.

Berrong, S.L., Washburn, K.W., 1998. Effects of genetic variation on total plasma protein, body weight gains, and body temperature responses to heat stress. Poult. Sci. 77, 379-385.

Bottje, W.G., Harrison, P.C., 1985. Effect of carbonated water on growth performance of cockerels subjected to constant and cyclic heat stress temperatures. Poult. Sci. 64, 1285-1292.

Cahaner, A., Pinchasov, Y., Nir, I., Nitsan, Z., 1995. Effects of dietary protein under high ambient temperature on body weight, breast meat yield, and abdominal fat deposition of broiler stocks differing in growth rate and fatness. Poult. Sci. 74, 968-975. 
Cardeau S. and Barrington S. (2010). Heat balance for two commercial broiler barns with solar preheated ventilation air. Biosystems Engineering, 107, 232-241.

Felver-Gant, J.N., Mack, L.A., Dennis, R.L., Eicher, S.D., Cheng, H.W., 2012. Genetic variations alter physiological responses following heat stress in 2 strains of laying hens. Poult. Sci. 91, 1542-1551.

Franco-Jimenez, D.J., Scheideler, S.E., Kittok, R.J., Brown-Brandl, T.M., Robeson, L.R., Taira, H., Beck,M.M., 2007. Differential effects of heat stress in three strains of laying hens. J. Appl. Poult. Res. 16, 628-634.

Geraert, P.A., Guillaumin, S., Leclercq, B., 1993. Are genetically lean broilers more resistant to hot climate? Br. Poult. Sci. 34, 643-653.

Hashizawa, Y., Kubota, M., Kadowaki, M., Fujimura, S., 2013. Effect of dietary vitamin $\mathrm{E}$ on broilermeat qualities, color,water-holding capacity and shear force value, under heat stress conditions. J. Anim. Sci. 84, 732-736.

Jekayinfa S. O. (2007). Energetic analysis of poultry processing operations. Leonardo J. Sci., 7(6):77-92.

Lin, H., Jiao, H.C., Buyse, J., Decuypere, E., 2006. Strategies for preventing heat stress in poultry. Worlds Poult. Sci. J. 62, 71-86.

Lindley J.A. and J.H. Whitaker, Agricultural Buildings and Structures, ASAE, St. Joseph, Michigan, USA.

Lu, Q.,Wen, J., Zhang, H., 2007. Effect of chronic heat exposure on fat deposition and meat quality in two genetic types of chicken. Poult. Sci. 86, 1059-1064.

Samer M., C. Loebsinb, M. Fiedlera, C. Ammona, W. Berga, P. Sanftlebenb and R. Brunscha (2011). Heat balance and tracer gas technique for airflow rates measurement and gaseous emissions quantification in naturally ventilated livestock buildings. Energy and Buildings 43 (2011): 3718-3728 
Sandercock, D.A., Hunter, R.R., Nute, G.R., Mitchell, M.A., Hocking, P.M., 2001. Acute heat stress-induced alterations in blood acidbase status and skeletal muscle membrane integrity in broiler chickens at two ages: implications for meat quality. Poult. Sci. 80, 418-425.

Soleimani, A.F., Zulkifli, I., Omar, A.R., Raha, A.R., 2011. Physiological responses of 3 chicken breeds to acute heat stress. Poult. Sci. 90, 1435-1440.

Star, L., Decuypere, E., Parmentier, H.K., Kemp, B., 2008. Effect of single or combined climatic and hygienic stress in four layer lines:

2. Endocrine and oxidative stress responses. Poult. Sci. 87, 10311038.

Tan, G.Y., Yang, L., Fu, Y.Q., Feng, J.H., Zhang,M.H., 2010. Effects of different acute high ambient temperatures on function of hepatic mitochondrial respiration, antioxidative enzymes, and oxidative injury in broiler chickens. Poult. Sci. 89, 115-122.

Vigoderis, I. Tinoco, M. Cordeiro, M. Bueno, R. Gates, J. Silva, R. (2008). Performance Evaluation of Broilers under Different Heating Systems in the South of Brazil, American Society of American and Biological Engineers, St. Joseph, MI.

Washburn, K.W., Peavey, R., Renwick, G.M., 1980. Relationship of strain variation and feed restriction to variation in blood pressure and response to heat stress. Poult. Sci. 59, 2586-2588.

Yahav, S., Goldfeld, S., Plavnik, I., Hurwitz, S., 1995. Physiological responses of chickens and turkeys to relative humidity during exposure to high ambient temperature. J. Therm. Biol. 20, 245253.

Young, R.A., 1990. Stress proteins and immunology. Immunol. Annu. Rev. Immunol. 8, 401-420. 
الملخص العربي

\title{
تطوير برنامج حاسوب لتقدير طاقة التدفئة فى مساكن دجاج اللحم
}

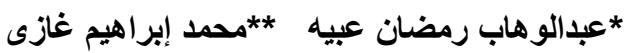

أجريت تلك الدر اسة فى مزر عة دجاج لحم، بمنطقة الجبل الأخضر ، مدينة البيضاء، ليبيا،، بهدف تطوير برنامج حاسوب لتقدير طاقة التدفئة المستخدمة فى مزارع دجاج اللحم تحت ظروف

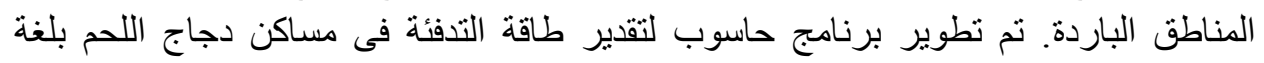

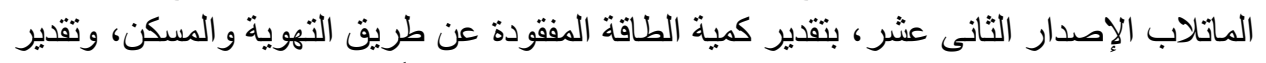
كمية الطاقة الناتجة من الطيور بالمسكن. تم تجميع البيانات حقلياً والخاصة بتقدير طاقة التدفئة التئة

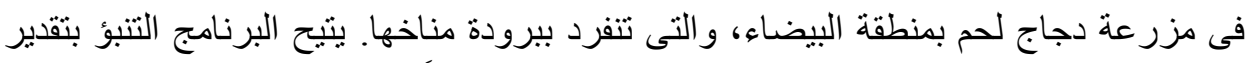

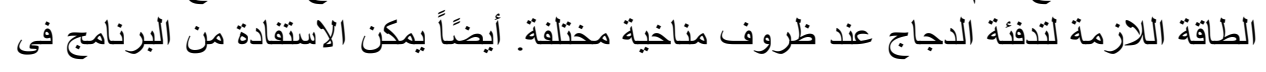

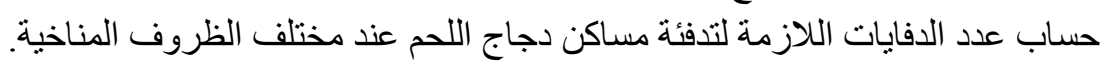

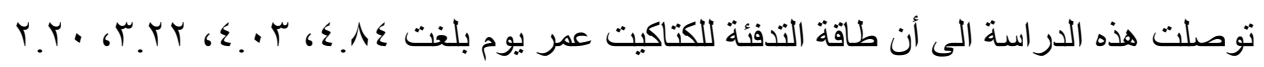

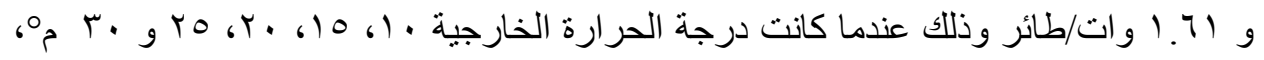

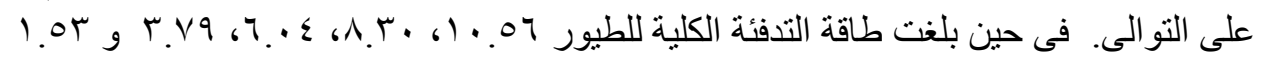

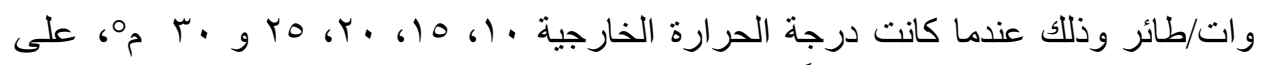

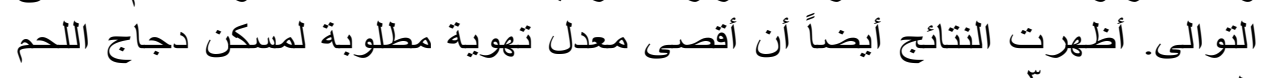

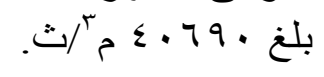

*باحث أول - معهد بحوث الهندسة الزراعية - الدقى - الجيزة.

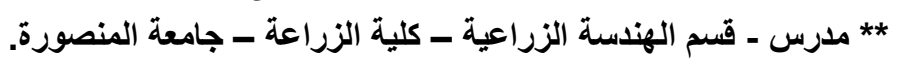

